\title{
17q21 Microdeletion Syndrome
}

National Cancer Institute

\section{Source}

National Cancer Institute. 17 q21 Microdeletion Syndrome. NCI Thesaurus. Code C75470.

A genetic syndrome caused by microdeletions in chromosome 17q21. The microdeletions encompass the MAPT and CRHR1 genes. It is characterized by mental retardation, hypotonia, distinctive facial features (long face, low-set ears, and pearshaped nose), friendly behavior, and heart defects. 